\title{
A imigração Armênia no Brasil e as comunidades em São Paulo.
}

\author{
Sonia Maria de Freitas*
}

Eu quero ver qualquer poder do mundo destruir esta raça... Vá em frente, destrua a Armênia. Veja se pode fazê-lo. Mande-os para o deserto, sem pão e sem água. Queime seus lares e igreja. E veja se eles não riem, cantam e rezam de novo. Quando dois deles se encontrarem em qualquer parte do mundo, veja se não criam uma Nova Armênia.

William Saroyan

No mês de abril de 2015, armênios e descendentes de diversos países celebraram o Centenário do Genocídio Arménio, praticado pela Turquia Otomana, e considerado o protótipo de genocídio moderno. A efeméride levounos a refletir sobre este fenômeno e outros genocídios que têm ocorrido ao longo dos séculos XX e XXI: Holocausto, ex-lugoslávia, Ruanda. Na atualidade intensificam-se massacres de minorias étnicas em diversos países africanos, árabes, entre outros, que são verdadeiros crimes contra a humanidade. As ações de organismos internacionais têm sido morosas ou pouco eficazes.

Salientamos que a memória não se limita a registrar eventos do passado, como nos adverte Le Goff (1984: 24), "a memória, onde cresce a história, que por sua vez a alimenta, procura salvar o passado para servir o presente e o futuro". Este trabalho tem por objetivo apresentar o contexto histórico que determinou a vinda de armênios para o Brasil, sobretudo para o estado de São Paulo, bem como apresentar a história dessa imigração e a conseqüente constituição deste grupo étnico, tendo como base a literatura disponível, mas, sobretudo, as narrativas e relatos dos próprios imigrantes e descendentes. Foram realizadas dezoito entrevistas, sendo doze com imigrantes e seis com descendentes, além de relatos sobre a trajetória de 32 famílias de imigrantes armênios.

Entre os entrevistados identificamos religiosos, profissionais liberais (pesquisador de mercado, advogado, arquiteto, engenheiro), professores universitários, marceneiros, tipógrafo, padeiro, alfaiate, mascate, comerciante e

\footnotetext{
* Doutora em História Oral pela USP

Pesquisadora aposentada do Museu da Imigração
} 
restaurador de tapete persa e armênio, comerciantes e fabricantes de roupas, de calçados, de malas, de papel, de celulose e embalagens, entre outras atividades. Entre os informantes, dezesseis chegaram antes dos anos 1920, 27 chegaram na década de 1920, e sete na década de 1930. A maioria dos armênios de São Paulo veio - ou são descendentes de imigrantes - da Armênia Ocidental (hoje território turco) ou da Cilícia (norte da Síria). Entre outras cidades, nasceram em Sis, Diaberkir, Cesaréia, Alexandropol, Aintab, Albustan, Marach e, também em Beirute (Líbano) e Alepo (Síria).

\section{Império Otomano: a convivência entre turcos e armênios}

Durante o Império Otomano (1299-1922), os armênios tiveram uma coexistência pacífica com os turcos. Havia tolerância por parte do governo turco que lhes concedeu direitos religiosos e civis. Mas eles eram considerados uma espécie de cidadãos de segunda categoria. Não tinham os mesmos direitos dos turcos e estavam sujeitos ao pagamento de taxas frequentemente extorsivas. Os armênios prosperaram, e muitos ocuparam posições de destaque como banqueiros, financistas, comerciantes. Chegaram a ter uma situação semelhante a dos judeus na Europa, que constituíam uma minoria religiosa, mas muito ativa economicamente.

Os armênios reagiram à força econômica do mundo industrializado mais rapidamente que a maioria da população, e alcançaram uma presença econômica importante na Turquia, fora de proporção em relação à sua presença numérica. Embora integrados à economia do Império Otomano, os armênios eram culturalmente distintos. Moravam em bairros separados e era impensável um casamento entre turcos e armênios (Miller \& Miller, 1993: 35).

A filha de armênios Haiganuch Sarian ilustra bem a questão lembrando-nos que o domínio turco era, a princípio, amistoso:

(...) então as minhas lembranças de infância vêm mais do que contavam os meus tios. Parece que houve um período em que o contato com os turcos era bastante amistoso, e isso não só entre armênios e turcos, mas entre outra comunidade que teve um destino muito parecido com o destino dos armênios, que é a comunidade grega da Turquia. Então, tanto gregos quanto armênios se entendiam bem com os turcos. A coisa começou a se tornar conflitante quando os turcos começaram a temer um pouco uma espécie de liderança intelectual e econômica armênia; aí então é que começaram certas perseguições, certas dificuldades, até culminarem com os acontecimentos 
de 1915. Tanto, no começo, havia um convívio bastante amistoso entre armênios e turcos, que os armênios falavam [o idioma] turco em casa. Basta dizer que aqui em São Paulo há muitas famílias armênias que ainda têm o hábito de falar o turco em casa. Então junto com o armênio falavam o turco". (nascida em São José do Rio Preto, em 1938). ${ }^{2}$

Durante o século XIX, na cidade de Constantinopla (Istambul) formou-se um importante grupo de intelectuais armênios, que foram influenciados pelos ideais de liberdade e autodeterminação dos povos apregoados desde a Revolução Francesa de 1789. Ideais estes absorvidos por estudantes armênios que foram estudar na França, Alemanha, Itália e Estados Unidos. Os armênios viveram um despertar cultural, manifestado pela construção de escolas e bibliotecas, publicação de livros e jornais e o desenvolvimento da literatura no vernáculo. Khatchatour Apovian (1805-1848) é considerado o "pai da literatura armênia moderna". Com ele teve início a escrita em linguagem popular, quando até então só a linguagem erudita era utilizada. $O$ verso abaixo do poeta armênio Khatchatour Apovian ilustra bem o sentimento nacionalista:

\section{Mesmo que me acorrentem os pés, amarrem minhas mãos, tapem a minha boca, meu coração gritará por liberdade.}

Esse nacionalismo intensificou-se e levou à criação de partidos políticos no final do século XIX - o Henchakian, Federação Revolucionária Armênia e o Rangavar. Os armênios começam a reivindicar autonomia e, em decorrência, os turcos passam a perseguir e a massacrar a população armênia.

Entre os anos 1915/18, houve o genocídio de 1,5 milhão de armênios pelo Império Otomano. A prática do genocídio como arma de expansão territorial foi aprimorada pelos nazistas no holocausto dos judeus na Segunda Guerra Mundial. O governo turco, que se aliou à Alemanha na Primeira Guerra Mundial, acusou os armênios de estarem passando para o lado dos inimigos russos no Leste. Foi esse o pretexto para que fosse dada a ordem para a deportação e a matança dos armênios. Talaat Paxá, ministro do Interior do Império Otomano e um dos líderes do movimento nacionalista Jovens Turcos, que controlava o governo otomano desde 1908, ordenou:

O governo decidiu aniquilar inteiramente todos os armênios que moram na Turquia. Por mais trágico que possa parecer o recurso da aniquilação, é preciso dar um fim à existência deles, sem consideração por mulheres, crianças ou doentes, sem dar ouvidos aos sentimentos e à consciência. 15 de setembro de 1915. Ministro do Interior Talaat" (BASÍlıO, 1994, p.244) . 
No final do século XIX e início do XX, houve movimentos migratórios de armênios, em virtude da onda de massacres. As cidades de Marach e Sis tornaram-se pólos desta população em trânsito. Os soldados turcos invadiam as aldeias, as vilas e as cidades, incendiando as casas de armênios, obrigando-os à longa peregrinação através dos desertos da Síria e Mesopotâmia. Desta maneira eram condenados à morte. Muitos sobreviventes foram agrupados em campos de refugiados mantidos pela Liga das Nações e milhares de crianças órfãs recolhidas em orfanatos mantidos pelas igrejas católicas e protestantes no Líbano.

Cenas da violência e do genocídio turco foram presenciadas por embaixadores de alguns países:

Até os embaixadores dos Estados Unidos, da França e da Inglaterra ficaram contra os turcos, porque eles mandaram dizimar mesmo. Muita gente. Eles mataram crianças, mulheres. Mulheres jovens, eles levavam, como escravas, concubinas. Muitas mães mataram o próprio filho, as filhas para não entregar para eles. E o meu pai disse, que quando fugiam - quando ele contava eu chorava - no caminho, para poder escapar, muitas mães sufocavam os bebês para poder salvar os maiores, porque se choravam os turcos sabiam onde estavam escondidos. (Varvarisa Nersessian, Araçatuba, 1930). ${ }^{4}$

Os armênios não vivenciaram o massacre passivamente. Ao contrário, eles resistiram travando longas batalhas contra os turcos e causando muitas baixas como as de Zeitun, Sassun, Van. As mulheres de Zeitun eram guerreiras e lutavam ao lado dos homens. A bravura armênia é lembrada quando, na montanha costeira de Mussa-Dagh, quatro mil soldados resistiram durante 40 dias a um grande número de soldados turcos. Alguns imigrantes que vieram para o Brasil chegaram a integrar a resistência, tornando-se guerrilheiros. Fotografias e até as armas usadas durante a guerra foram a nós apresentadas como prova da veracidade de seus depoimentos, como o de Yeranouhi Mavian.

Além daquela população desenraizada dos campos de refugiados e dos orfanatos, Roberto Grun aponta que

\footnotetext{
os armênios que moravam em diversos pontos do antigo Império Otomano começam a emigrar maciçamente, temendo novos massacres e fugindo não só da turbulência política e econômica, como também do serviço militar obrigatório no Exército Turco, que acabava de instituir a conscrição universal (GRUN: 1992, p.17). ${ }^{5}$
}

Ao saírem da Turquia os armênios se refugiaram, inicialmente, em lugares da mesma área geográfica, como na Síria e, depois, no Líbano que naquele tempo constituíam um só país. Para se ter uma ideia da grande concentração de armênios nesses países, que ainda hoje contam com uma população armênia significativa, na cidade de Kessab, na Síria, por exemplo, $80 \%$ da população era armênia. ${ }^{6}$ 
Durante a década de 1920, os armênios emigraram para diversas partes do mundo, principalmente para a Europa, América do Norte e América do Sul. Hoje, além da República da Armênia, eles são encontrados principalmente nos Estados Unidos, Rússia, França, Líbano, Síria, Turquia, Irã, Polônia, Canadá, Azerbaijão, Geórgia, Ucrânia, Argentina, Austrália, Alemanha, Bulgária e Brasil.

\section{Memórias e trajetórias dos Armênios do Brasil}

No Brasil, os imigrantes armênios fixaram-se principalmente nos Estados do Rio de Janeiro, Mato Grosso do Sul e São Paulo. Para a cidade do Rio de Janeiro se dirigiram cerca de 100 famílias, entre elas 58 são provenientes do Líbano (Beirute), Egito, Grécia, Armênia, Turquia (Istambul), Líbia, França, Argentina (Buenos Aires), Irã, Itália e Estados Unidos. Desse total, 44 famílias chegaram após a Segunda Guerra Mundial. Ali se dedicaram à atividade comercial: comércio de bijuterias nas ruas da Alfândega e Senhor dos Passos, comércio e lapidação de pedras (cristal de quartzo), ourivesaria, joalheria e construção civil. Os descendentes dos armênios tornaram-se profissionais liberais (médicos, químicos, geólogos, dentistas, engenheiros), oficiais da marinha, entre outras. ${ }^{7}$

No atual Estado do Mato Grosso do Sul, os armênios chegaram na década de 1920. Ali se tornaram mascates no Interior do Estado, atingindo a região de garimpo de Corguinho-MS e Rochedo-MS. Encontramos famílias armênias principalmente na cidade de Campo Grande-MS, onde participaram da formação do comércio no centro da cidade com mais de 16 estabelecimentos comerciais. ${ }^{8}$

No Estado de São Paulo, alguns armênios chegaram no final do século XIX e primeira década do século XX, mas a maioria veio em meados dos anos 1920 (1925 e 1926). Registra-se também uma pequena leva, vinda após a Segunda Guerra Mundial.

Como os sírios e libaneses, os armênios que vieram no final do século XIX dedicaram-se ao comércio ambulante e, em poucos anos, conseguiram fazer fortunas. Entre os que aportaram naquele período destacam-se as famílias Gasparian, Keutenedjian, Rizkallah Jorge Tahanian. As duas primeiras investiram no setor têxtil, possuindo fábricas e lojas de tecidos, como o Lanifício Varan, Gasparian \& Fileppo.

Na memória desses imigrantes permanece o importante papel desempenhado por Varan Keutenedjian e por Rizkallah Jorge Tahanian. Varan hospedava os recém-chegados em sua chácara Cruzeiro do Sul, no bairro da Penha. Rizkallah é considerado um grande benemérito da colônia. Bem estabelecido com o seu próspero negócio - a Casa da Bóia - ele ajudava os recém-chegados, acolhendo-os num casarão que possuía na esquina da rua Anhangabaú (atual 25 de Março) com a Barão de Duprat, ou no prédio da sua loja, ou 
(...) Na própria casa dele, lá em cima, em cima da Casa da Bóia, ele dava abrigo, chamava os parentes, amigos $e$ coligados aos amigos, e dava hospedagem. Muitas vezes até dava trabalho, trabalho lá na fábrica, na loja". (Antonio Jorge Rizkallah Neto, São Paulo, 1932). ${ }^{9}$

Embora tenha sido uma imigração eminentemente urbana, alguns armênios vindos nos anos 1910 e 1920 foram para a lavoura de algodão e de café. A família de Garabed Hocharian chegou ao Brasil em 29 de agosto de 1925, junto com 25 famílias, num total de 108 pessoas. Permaneceram cinco dias na Hospedaria de Imigrantes em São Paulo, de onde partiram para a colheita de café na fazenda Canaã, na região de São Simão. ${ }^{10}$

Nesse estado estabeleceram-se como comerciantes na região da Noroeste (Araçatuba, Lins, Birigui, São José do Rio Preto, Garça), em Ribeirão Preto, Osasco, Ferraz de Vasconcelos e na cidade de São Paulo.

\section{A comunidade de Osasco-SP e do bairro Presidente Altino}

Atraída pelos baixos preços dos terrenos, uma parcela dos armênios instalouse no município de Osasco-SP, no bairro de Presidente Altino, na época locais distantes da capital paulista. Ali trabalharam na Cerâmica Hervy e no Frigorífico Wilson. Dedicaram-se também à criação de gado leiteiro e à produção de iogurtes e coalhadas, que vendiam em São Paulo-SP. Em 1928, esses imigrantes compraram um terreno com o objetivo de construir uma igreja. Levantaram as paredes e para concluí-la receberam ajuda de Varan Keutenedjian, que também abrigava famílias de imigrantes. Em 1932, ainda com o chão de terra batida, foi celebrada a primeira missa na igreja São João Batista, localizada na Rua Carlos da Costa Ramalho Junior, a primeira igreja armênia do Brasil que no início também abrigou a escola armênia. A emoção da inauguração da igreja é narrada por Archaluz Kurkdjian, cujos pais integraram a comissão responsável pela construção:

Foi tudo com muito sacrifício, inclusive os pais da gente tiravam até da boca dos filhos para poder construir essa igreja. Levou muito tempo... para estar com a situação financeira boa, aí eles fizeram uma comissão [..]. a gente tinha muitos parentes que moravam na capital, como ia ser inaugurado, vieram muitos parentes e amigos, no sábado, porque no domingo ia ter a primeira missa. Presidente Altino era um lugar de veraneio pra eles, porque ninguém tinha onde passear, então era uma festa vir para Osasco, para Presidente Altino". (nascida em São Paulo-SP, em 1935). ${ }^{11}$

Em 1942, a comunidade fundou a Sociedade Esportiva e Cultural-Mocidade Armênia de Presidente Altino-SEC-MAPA com o objetivo de realizar atividades sociais, culturais e esportivas. A Sociedade manteve uma escola que, além das discilinas obrigatórias, ensinava a língua e a história da Armênia. 


\section{A comunidade de Ferraz de Vasconcelos}

Em meados de 1930, entre um grupo de armênios de São Paulo circulou a notícia da existência de uma cidade com topografia similar a Marach, sua terra natal, e que com uma única passagem de trem Maria-Fumaça lá se chegava. Relatou-nos Sergio Semerdjian, neto de um dos integrantes do grupo. ${ }^{12}$ Dessa maneira, um patrício levou o outro, formando cerca de 23 chácaras de 6.000 a $10.000 \mathrm{~m} 2$, uma ao lado da outra, com plantação de uva, pêssego e maçã, no bairro Romanópolis daquela localidade. Trouxeram a experiência milenar de cultivo da videira, tradição da Armênia. A viticultura nasceu entre a Armênia e a Pérsia, na ampla região delimitada pelos mares Negro, Cáucaso e Cáspio, e, pelos maciços do Ararat e do Taurus. De acordo com Cruz e Souza (1969: 16):

[...] ao encontro da documentação arqueológica e de outras pesquisas cientificas, vêm as mais pitorescas tradições bíblicas consagrar como nascedouro do cultivo da videira as encostas do Ararat, onde Noé, baixando da arca à terra, ali amanhou a parra, abusou do vinho que fez de seus frutos e foi escarnecido pelo filho ingrato - rezam os versículos 20 e 21, capítulo IX, Gênesis".

Da Armênia, a viticultura se espalhou por toda a Ásia Menor, Trácia, Península Balcânica. Em direção ao sul, foi para a Síria, Egito, Creta, e, depois, transportada pelos fenícios, chegou a Roma, Gália e outros povos do mediterrâneo.

Hoje, no município de Ferraz de Vasconcelos, há uma rua no bairro Romanópolis denominada Armênia. Entre os proprietários das chácaras estavam, dentre outros, os Arakelian, Dadian, Danielian, Pilavjian, Tchakmakian, Ervazian, Asdourian e Semerdjian. Essa última família mantém a sua chácara em atividade que também foi transformada em museu.

\section{Os Armênios na capital paulista}

Em São Paulo-SP, os armênios concentraram-se inicialmente nos bairros da Luz, Santana e na região do mercado Central. Hoje, são também encontrados nos elegantes bairros dos Jardins e Moema. Trabalharam como mascates, pequenos comerciantes, operários, mas se dedicaram principalmente ao comércio. A professora aposentada de arqueologia da USP e filha de imigrante, Haiganuch Sarian, falou da vocação do armênio para o comércio:

(...) os armênios não têm vocação só para o comércio, porque eles se sobressaem em vários outros oficios. Agora a vocação para o comércio é uma vocação nata, em todo o Oriente Médio, não são apenas os armênios. Os sírios, os libaneses, os egípcios, todo o Oriente Médio e Próximo têm essa vocação mercantil; os gregos também. Isso 
vem da mais alta Antigüidade. O comércio e as trocas na Antigüidade armênia e no Médio Oriental chegou a ser muito desenvolvido, a tal ponto que, os herdeiros do comércio mesopotâmico ou do comércio de Urartu e do comércio dos hititas foram os fenícios. Os fenícios eram grandes mercadores e grandes negociantes, então isso é uma coisa que está realmente na natureza [dos povos] do Oriente Médio e Próximo. ${ }^{13}$

O comércio ambulante não foi abandonado pelos imigrantes dos anos 1920, como relata Karnig Bazarian:

(...) comecei como mascate. Vendia bugigangas, coisas na mão: gravatas, miudezas tal coisa. Em dia de chuva, saia na rua, se não vendesse 2 pares de meia, eu não almoçava, fazia economia. À noite eu trabalhava ... daí eu viajava, de noite viajava com caminhão para não gastar ônibus, de dia trabalhava na zona de Buri, Guareí, Sarapui, Capão Bonito. Tenho mais de 40 afilhados naquela zona, eu fui muito conhecido lá em Itapetininga... Na mala levava meias, além de gravatas, meias, blusas, tudo o que pertencia para senhoras, cintas, essas coisas. É mascatear... de cidade em cidade, e depois domingos e feriados [ia a] algumas festas, abria barraca lá, vendendo tudo que tivesse (...). (Karnig Bazarian, Marach, Armênia Turca, 1908). ${ }^{14}$

\section{O predomínio armênio na confecção de calçados}

Registra-se a presença de armênios no ramo de confecção de roupas, mas os armênios na capital predominaram no ramo de confecção e comércio de calçados. Existe um mito no grupo de que os armênios que chegaram nos anos 1920, vindos da região da antiga Cilícia, eram hábeis artesãos em couro, principalmente de "babuchas" (chinelos) e de selas. Os depoimentos confirmam a concentração de armênios no ramo de calçados que, segundo Grun, era um

\footnotetext{
(...) ramo mole, de baixa composição orgânica de capital e sem barreiras para entrada, onde é fácil se instalar, em termos estritamente econômicos, principalmente dispondo de conhecimento do ofício e o (...) aproveitamento de uma oportunidade de um vazio existente na sociedade urbana paulista em formação. (GRUN; 1992: 56 e 92).
}

No Calendário Armênio publicado em 1941, impresso na Tipografia Massis, por Garabed Amiralian, identificamos 48 patrocinadores pertencentes a este grupo étnico. Deste total, 24 (50\%) eram fabricantes de calçados; 15 (31\%) tinham confecção e comércio de artigos masculinos como camisas, pijamas, gravatas, chapéus, bonés e indústria e comércio de tecidos e fios. Os demais, 9 
patrocinadores (18\%), comercializavam tapetes, secos e molhados, amortecedores de carro, venda e conserto de rádio, cutelaria e borracha, comércio e fabricação de sombrinhas, loja de douração e prateação, e um cirurgião dentista.

A maioria desses armênios abriu fábricas de calçados na rua Pagé (hoje comendador Afonso Kherlakian), rua 25 de Março, rua Mauá, rua Anhangabaú, rua Senador Queiroz e rua Barão de Duprat.

Segundo relatou-nos Sergio Semerdjian, do ramo de calçados e neto de Ohannes Semerdjian, seu avô quando chegou a São Paulo, em 28 de dezembro de 1928, foi morar na rua Santo André, zona do mercado central, onde alugaram um sobrado com outras famílias e começaram a fabricar uma dúzia de chinelos de lã por dia, sendo o material comprado do cotonifício Varan Keutenedjian ${ }^{15}$. Ohannes cortava, montava e vendia pelas ruas e a avó Haiganuch Kumruian costurava. Em pouco tempo de trabalho, ele comprou uma máquina nova de costura que foi atirada pela sacada, porque a sua esposa lhe falou que "graças a ela, ele havia comprado aquela máquina". Em dois anos montou uma pequena fábrica - Chinelo Ohanes Semerdjian \& Filhos - na rua Pagé e, em 1933, alugou no n. 5 da mesma rua uma propriedade de 100 m2, de Abrão Beirute, amigo dos armênios da região. A partir de 1940, essa fábrica foi denominada Chinelos Sarkis e por último, em março de 1947, a fábrica mudou-se para prédio próprio de 1000 m2, passando a chamar-se Chinelos Merci. O pai de Sergio, Sarkis, e seu tio Hadji montaram a primeira fábrica de máquinas para calçados denominada Indústria Paulista de Máquinas para Calçados Ltda., no início da década de 1950. A família continua com a fábrica e comércio de calçados até hoje.

Os imigrantes se concentram na confecção de calçados. Seus filhos e netos (primeira e segunda gerações de descendentes) se dedicam mais à venda do que à confecção de calçados. Semerdjian e Chofakian, do ramo de calçados, afirmam que existem mais de 200 lojas e mais de 50 fábricas nas mãos deste grupo étnico. Algumas lojas se expandiram formando redes constituídas por mais de 30 delas. Apenas para citar algumas: Casas Alegria, Casas Mundial, DIC, Besni, Babuch, Calçados Clóvis, Jean Daniel, etc. Outra característica dos descendentes, diferentemente de seus antepassados que atendiam à população de baixa renda, seguiram a tendência atual do comércio e se estabeleceram nos shopping centers e em bairros de classe média alta da Capital. A Zoomp e a Khelf se destacam na confecção de roupas finas.

\section{O papel da igreja na manutenção da armenidade}

Os imigrantes armênios em São Paulo são evangélicos, católicos e ortodoxos que constituem a maioria. A Igreja Evangélica Armênia da av. do Estado, 1191, construída em 1933, é a mais antiga da cidade e já havia sido oficializada em 1927. Os evangélicos também construíram a Igreja Evangélica Filadélfia, da av. Pe. Pereira de Andrade, 545 e a Igreja Evangélica Irmãos Armênios, na rua Maria Curupaiti, 117. A igreja Armênia Católica São Gregório lluminador, fundada em 1935, está situada na av. Tiradentes, 718. 
A Igreja teve - e ainda tem - um papel fundamental para o armênio na diáspora, na manutenção de uma consciência nacional e étnica ${ }^{16}$. Nas décadas de 1960 até o final da década de 1980, o patriarca (papa) Vasken viveu os piores momentos da Igreja, em função do domínio soviético e das dificuldades para se articular com as Igrejas da diáspora. Para o arcebispo Datev Karibian, da Igreja Apostólica Armênia do Brasil, situada na av. Santos Dumont, 55, que recebe os armênios ortodoxos,

\begin{abstract}
(...) durante séculos, a igreja junto com o governo armênio $e$ junto com o povo armênio conviveu com o destino da armenidade. Foram perseguidos, atacados, e usurpados pelos povos inimigos, pelos povos do Oriente e do Ocidente. A Armênia foi dominada pelo Império Romano, pelo Império Bizantino, pela Pérsia seldjúcida e pelos árabes, etc. Em toda essa trajetória, a igreja também sofreu bastante. Mas graças à igreja Armênia! Porque a Nação Armênia manteve a sua nacionalidade e a sua cultura, através da sua língua e dos seus costumes. E foi assim que até hoje, [há] quase 2 mil anos existe o cristianismo na Armênia. Mas oficialmente, a Igreja Armênia existe há 1.700 anos. $^{17}$
\end{abstract}

O mesmo arcebispo relatou a origem da Igreja Apostólica Armênia e a sua importância para a comunidade, lembrando ainda que o povo armênio vivia sob o paganismo e que Armênia foi a primeira nação a adotar o cristianismo como religião do Estado em 301 (a Grécia adotou em 309 e Roma, em 327).

Na cidade de São Paulo-SP, a primeira igreja apostólica armênia São Jorge, foi construída na av. Senador Queiroz, na altura do n. 35. Em 21 de março de 1937 houve a sagração da pedra fundamental pelo padre Gabriel Samuelian e a inauguração em 10 de abril de 1938. A igreja foi consagrada pelo arcebispo prelado Karekin Khachadurian, em 24 de setembro de 1938. A última missa foi celebrada no dia 02 de maio de 1943. Sua demolição teve início em 10 de maio de 1943 , devido às obras de alargamento da avenida. ${ }^{18}$

A segunda igreja, também denominada São Jorge, foi construída na av. Santos Dumont (antiga av. Tiradentes), n. 55, tendo sua pedra fundamental sido lançada e sagrada pelo padre Gabriel Samuelian e padre Yeznig Vartanian, em 25 de março de 1945. A abertura oficial ocorreu em 03 de abril de 1949 e a consagração pelo arcebispo prelado titular Karekin Khachadurian, em 24 de abril de 1949, de acordo com a Ata de Reunião da Diretoria da Igreja, de 16 de março de $1949 .{ }^{19} \mathrm{Na}$ construção das duas igrejas, o apoio de Rizkallah Jorge foi fundamental, relatou-nos seu neto, Antonio Jorge Rizkallah Neto). ${ }^{20}$

\title{
Organização da comunidade em São Paulo
}

A comunidade armênia em São Paulo criou cerca de 30 entidades e instituições. Entre elas destacam-se: o Clube Armênio de caráter mais cultural e social , a Sociedade Beneficente de Damas Brasil-Armênia-HOM, a União Geral Armênia de Beneficência-UGAB, e a Sociedade Beneficente e Cultural Marachá. 


\section{Sociedade Beneficente de Damas Brasil-Armênia-HOM}

A Sociedade Beneficente de Damas Brasil-Armênia H.O.M (Hai Ognutium Miutium) é uma entidade de damas, com sede em Boston (EUA) e filiais em vários países, entre eles a Armênia. Realiza trabalho voluntário com os armênios e não-armênios necessitados de vários países, desde a sua fundação em 1910. No Brasil, a H.O.M, fundada na cidade de São Paulo em 21 de janeiro de 1934, mantém uma filial Arpí e a uma sucursal Massis em Osasco e conta com cerca de 600 sócias.

\section{A União Geral Armênia de Beneficência-UGAB}

Em meados da década de 1960, os armênios de São Paulo já estabelecidos social e economicamente, vislumbraram a oportunidade de trazer para o Brasil os princípios ugabianos que já tinham se espalhado por vários países. ${ }^{21}$ Assim, em $1^{\circ}$ de setembro de 1964, um grupo formado por 23 armênios reuniu-se na Indústria de Calçados Merci, pertencente à familia Semerdjian e ali plantaram a semente da UGAB. Desde seu início, essa entidade - como as suas similares de outros países - tem por objetivo principal a formação física e intelectual das futuras gerações, bem como dar assistência social aos carentes ${ }^{22}$.

Por vários anos a diretoria se reunia nas residências e escritórios dos diretores, mas a partir de 27 de novembro de 1967, a UGAB se instalou em sede própria no edifício Guarany, no parque Dom Pedro II, onde permaneceu até 1974. A partir dessa data foi transferida para a rua Natingui, 1545, onde foi construído o Complexo Educacional, Social, Esportivo e Cultural Alex Manoogian. Nesse espaço, construiu-se o edifício educacional Escola Paren e Regina Bazarian e ginásio de esportes Hagop Mavian.

Entre as publicações da entidade destaca-se a revista Nor Ani, com vários números editados a partir de 1982 e o Informativo IRIS, órgão de circulação mensal, editado desde 1982. Ambos voltados à história e à cultura armênias, além de divulgar assuntos de interesse da coletividade.

\section{Sociedade Recreativa Marachá}

A Sociedade Recreativa Marachá foi idealizada e oficialmente organizada na casa de Karning Bazarian, na rua Augusta, 780, conforme a ata da primeira reunião, ocorrida em 20 de julho de 1947, com a presença de 14 pessoas. Mas uma reunião realizada no salão do Centro Armênio, em 15 de novembro, já contava com 95 pessoas. Em 1949, a Sociedade foi instalada na rua 25 de março, 1.129. A construção da sede própria na rua Santos Dumont, 42, teve ajuda da comunidade e até da Fundação Calouste Gulbenkiann ${ }^{23}$ (milionário nascido em Scutari em 1869, na atual Turquia, que era chamado de - "Mr. Five Percent", - o senhor 5\%", porque ele se associou aos petroleiros e, tendo parte em cada poço que abria, obtia $5 \%$ de todo o petróleo descoberto. Ele tornou-se um mito para os armênios). ${ }^{24}$ De acordo com Karnig Bazarian, a Marachá tinha por objetivos: 
as atividades culturais, artísticas, esportivas e filantrópicas, tais como ajudar os necessitados, celebrar missas anualmente em intenção dos mártires tombados em Marach, no massacre de 1920, bem como reunir a geração dos filhos da Marachá, organizar piqueniques, bailes, audições, etc. (Bazarian: 1988: 38 e 41).

As publicações mais freqüentes da comunidade são os boletins das igrejas. Com exceção da obra de Roberto Grun, Negócios \& Famílias (1992), sobre a relação entre a atividade econômica desse grupo e seu substrato cultural, não há um trabalho acadêmico voltado para a memória/história da imigração armênia no Brasil. Diferentemente, nos Estados Unidos, onde a comunidade armênia é estimada em 1.5 milhão, já foram publicados mais de 60 livros e artigos sobre esse tema. Em Los Angeles, Califórnia, onde se concentram mais de $\mathbf{3 0 0}$ mil armênios e descendentes, a coletividade conta com a edição de um jornal diário, além de instituições/fundações. ${ }^{25}$

\section{Armenidade}

Partidos políticos surgiram fora da Armênia, e em todas as comunidades dos diferentes países eles foram - ainda são - muito atuantes. Embora nenhum deles tenha conquistado a unanimidade, ainda mantêm as suas representações nas coletividades da diáspora ${ }^{26}$. Um motivo de união é a celebração do dia 24 de abril, data do início do genocídio, quando se realiza um ato ecumênico diante do monumento construído pela comunidade, em frente a Estação Armênia do Metrô, no bairro da Luz. Outra atividade supra-partidária é o Comitê Brasileiro para a Reconstrução da Armênia (Fundo Armênio), que arrecada doações em dinheiro para a Armênia. Criado por lideranças e entidades para socorrer as vítimas do terremoto ocorrido na Armênia em 7 de dezembro de 1988, esse fundo, denominado SOS Armênia, funcionou de 1989 a 1990. Com a independência da Armênia em 1991, passou a ser denominado Fundo Armênio e continuou ajudando nas dificuldades internas e na Guerra do Gharabagh ${ }^{27}$. As entidades armênias dos diversos países criaram uma comissão com trabalho permanente junto a Organização das Nações Unidas (ONU) e os governos para que o massacre cometido em 1915 seja reconhecido pelo governo turco, bem como seus territórios sejam devolvidos. Entre eles a região do Monte Ararat - o maior símbolo armênio e também a região mais fértil e produtiva - que se encontra em território turco anexado em 1917.

Para alguns informantes, o casamento interétnico, ocorrido principalmente na segunda geração de descendentes, é apontado como um problema na manutenção da armenidade. Para outros, embora muitos descendentes da segunda geração não falem a língua, eles não perderam o sentimento de pertencer ao grupo étnico. Para Chahinian, a língua não é mais um fator 
preponderante e o conceito sobre o que é um armênio está sofrendo mudança. Ele tem observado que muitos filhos de armênios estão buscando suas origens e se voltando para a coletividade e que:

(...) as entidades armênias do mundo inteiro estão participando ativamente na reconstrução da Armênia... netos de armênios até do exterior estão hoje dentro do país, trabalhando, produzindo e ajudando no progresso da Armênia". ${ }^{28}$

\section{Identidade Armênia no Século XXI}

Passados quatorze anos da realização da presente pesquisa, relatou-nos a professora universitária Sossi Amiralian, que a coletividade armênia hoje é muito mais dinâmica na organização de eventos e há uma maior interação dentro do próprio grupo e contatos com outros grupos étnicos. Aponta também uma maior integração e assimilação, havendo um maior interesse no 'resgate' na armenidade entre as novas gerações: com viagens à Armênia, eventos esportivos, estudos em diferentes áreas, convívio com famílias armênias.

Conforme tentamos demonstrar, o genocídio armênio foi a principal causa da diáspora deste grupo étnico que se espalhou por vários países. As memórias aqui apresentadas demonstram o drama, a perseverança, as lutas pela sobrevivência, a coragem de continuar resistindo para manter a sua identidade, e, pelo reconhecimento do genocídio armênio até hoje negado pela Turquia. Os armênios criaram o Conselho Nacional Armênio da América do Sul-CNA, entidade mundial com 88 escritórios em diversos países, incluindo o Brasil, que se dedica exclusivamente na defesa dos interesses armênios e à luta pelo reconhecimento do genocídio e o Comitê TRO - Comitê Armênio da Organização Revolucionária Tashnagstutiun. Mais de 20 paises reconhecem o genocídio armênio. $O$ Estado brasileiro ainda não reconhece. Apenas os Estados de São Paulo $(1989,2003)$, Paraná (2013), Ceará (2006), e as cidades de São Paulo-SP (2007), Campinas-SP (2011), Osasco-SP (2013), Fortaleza-CE (2005), São José do Rio Preto-SP (2006) reconhecem o genocídio.

Destaco ainda o papel desempenhado pelas redes sociais e, principalmente, pelo Portal Estação Armênia dedicado a eventos, notícias, culinária, história e memória, disponível no link http://estacaoarmenia.com.br/18289.

As memórias do genocídio são dolorosas, traumáticas, muitos se emocionaram ao narrá-las, mas não houve resistência em falar sobre o assunto. Atos de bravura de familiares guerrilheiros foram lembrados com muito orgulho. $\mathrm{Na}$ atualidade, o reencontro de famílias separadas pelo genocídio, e que se espalharam pelo mundo, tem sido facilitado pelos meios de comunicação como o correio, o telefone, Internet. Relatou-nos Panios Kelian, que foi encontrado pela lista telefônica por George seu parente que vive na Califórnia. 


\section{Galeria de retratos}

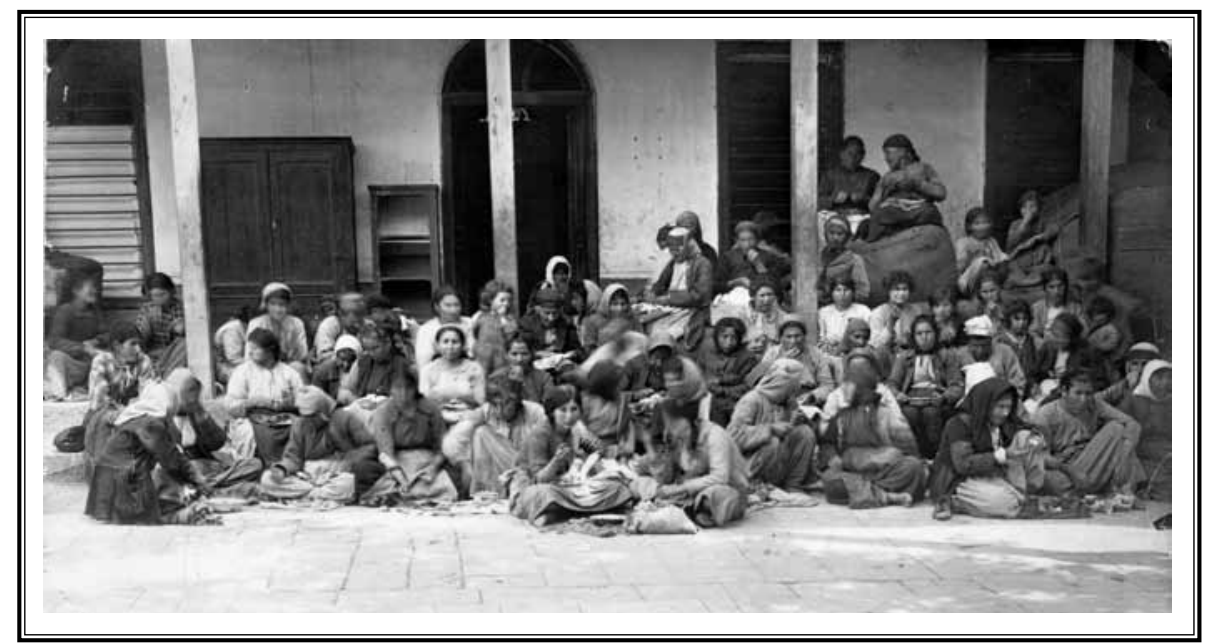

Refugiados armênios em Alepo, Síria. 1919.

Fonte: The Armenian Genocide Museum-Institute

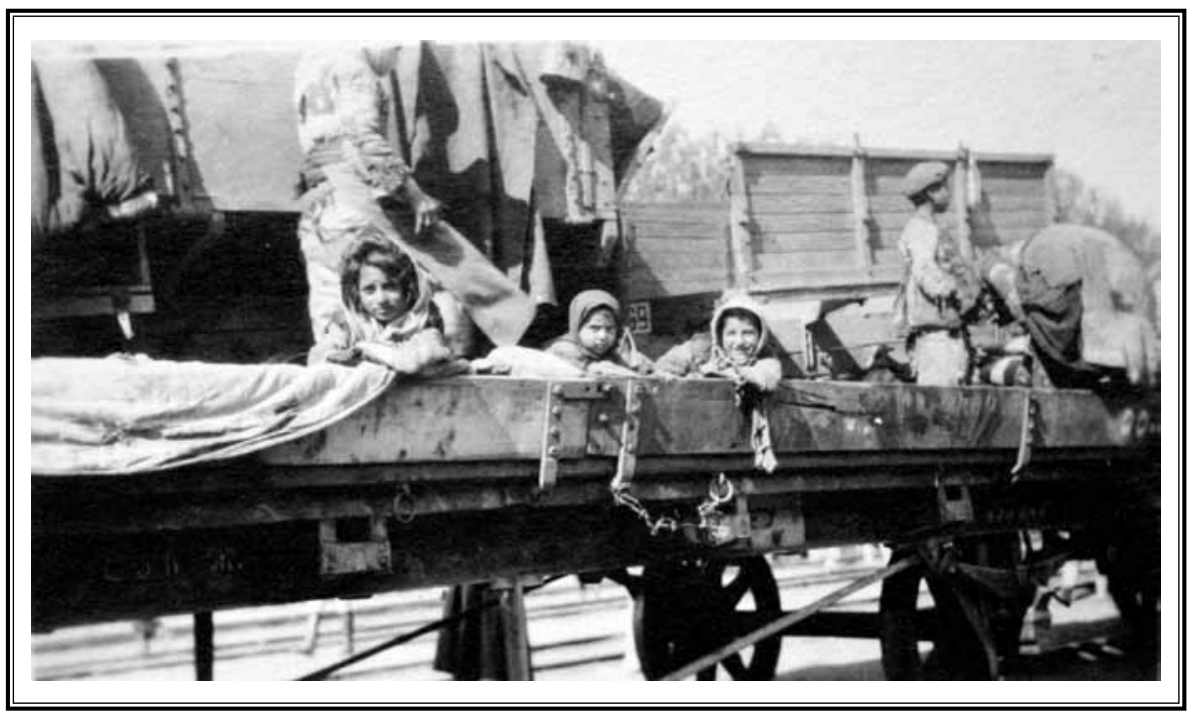

Crianças armênias repatriadas para Adana, Turquia, 1918. Em 1920, muitas delas foram mortas ou deportadas novamente.

Fonte: The Armenian Genocide Museum-Institute 


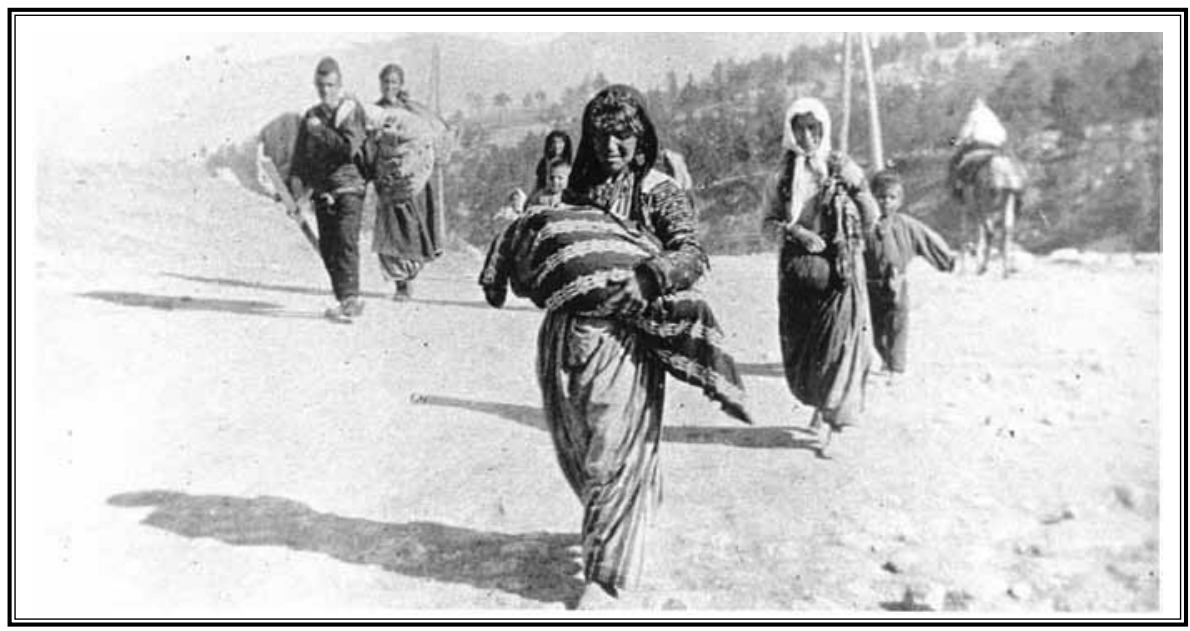

1915 - Armênios deportados: um grupo de mulheres, crianças e idosos fogem numa estrada de terra sem nenhum abrigo contra as intempéries. A mulher, à frente, carrega uma criança nos braços e a protege do sol com um xale; quase não se vê nenhum outro pertence ou alimento sendo carregado. Local: Império Otomano, na região da Síria. Crédito: Armenian National Institute, cedida por Sybil Stevens (filha de Amin T. Wegner, soldado alemão que registrou o Genocídio Armênio). Wegner Collection. Deutches Literaturarchiv, Marbach \& United States Holocaust Memorial Museum.

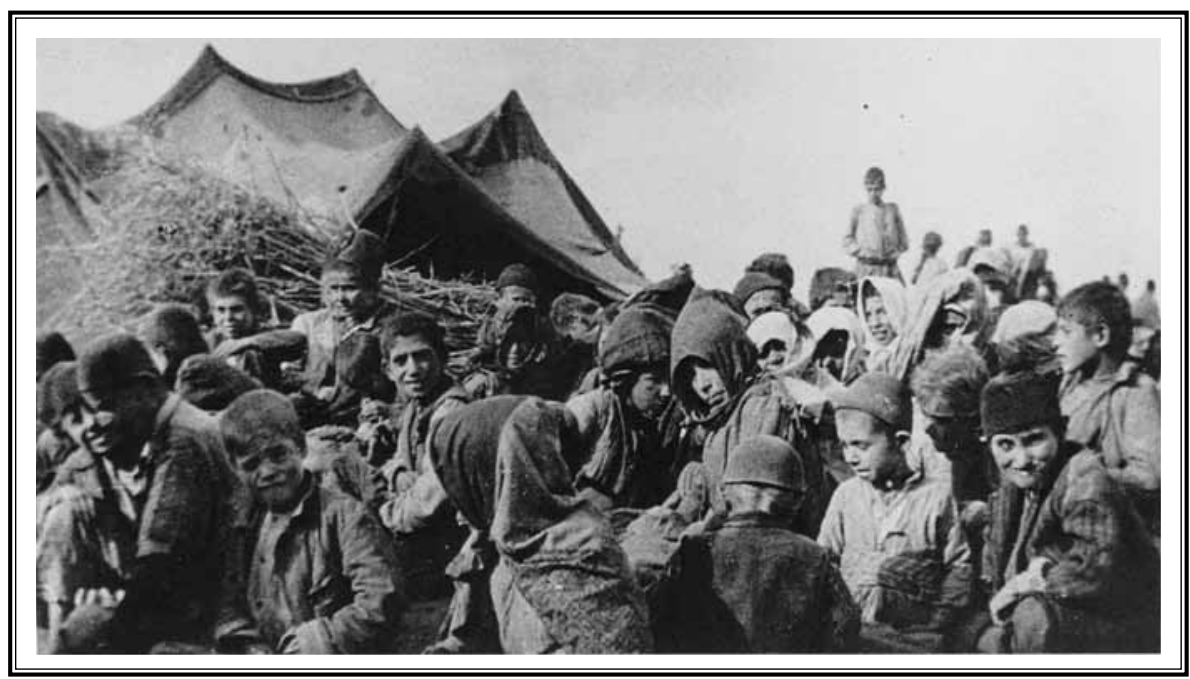

1915, crianças armênias órfãs a céu aberto, todas com roupas surradas e muitas cobrindo a cabeça como proteção contra o sol do deserto. Local: Império Otomano, na região da Síria. Crédito: Armenian National Institute, cedida por Sybil Stevens (filha de Amin T. Wegner, soldado alemão que registrou o Genocídio Armênio). Wegner Collection. Deutches Literaturarchiv, Marbach \& United States Holocaust Memorial Museum. 


\section{Notas}

1 Este artigo é uma síntese de texto sobre a imigração armênia, apresentado em minha tese de doutoramento defendida na Faculdade de Filosofia, Ciências e Letras, da Universidade de São Paulo, em 2001. A pesquisa, que contou com o apoio da comunidade armênia, foi realizada quando integrei a equipe do Museu da Imigração de São Paulo.

2 - Depoimento à autora em 30/6/2000.

3 - (Trecho de documento encontrado na cidade de Aleppo, Síria, após a derrota turca em 1918).

4 - Depoimento à autora em 14/7/2000.

5 - Depoimento de Panios Kelian à autora em 27/6/2000.

6 - Informaçao obtida através da relação de imigrantes armênios residentes no Rio de Janeiro, fornecida pela Sociedade Beneficente das Senhoras Armênias daquela cidade.

7 - Ver Migração: de como árabes e armênios se instalaram em Campo Grande. In : Arca. Arquivo Histórico de Campo Grande. n. 3. dez. 1992.

8 - Depoimento à autora em 01/8/2000.

9 - Dados confirmados no Livro de Registro de Imigrantes da Hospedaria de Imigrantes - agosto de 1925. Acervo: Museu da Imigração. São Paulo, SP.

10 - Depoimento à autora em 04/8/2000.

11 - Relato à autora em 13/9/2000.

12 - Depoimento à autora em 30/6/2000.

13 - Depoimento à autora em 25/7/2000.

14 - A Casa da Bóia, da família Rizkallah, fornecia os insumos (borracha, cola, salto, linha). As lojas de couro eram de propriedade de italianos instalados na av. Rangel Pestana. (Grun, op. cit. p. 48)

15 - Grun (1992) chama a atenção para o fato das organizações religiosas terem sido "depositárias da tradição e cultura da etnia, ainda no Oriente Médio, onde a nação armênia estava privada de um estado nacional pelo menos desde o século XIII".

16 - Depoimento à autora em 11/7/2000.

17 - Cf. VARTANIAN, Padre Yeznig. A coletividade Armênia no Brasil. Informações traduzidas e fornecidas à autora pela Diocese da Igreja Apostólica Armênia do Brasil.

19 - Traduzida e fornecida à autora pela Diocese da Igreja Apostólica Armênia do Brasil.

20 - Depoimento já citado.

21 - Fundada em 1906, estabelecendo caráter apolítico e condenando toda discriminação religiosa, a UGAB obteve credibilidade e apoio de toda a armenidade no mundo.

22 - Relato cedido à autora por Regina Bazarian, diretora da UGAB, em 22.9.2000.

23 - Calouste Gulbenkian doou 70 milhões de libras e uma valiosa coleção de arte, artefatos e documentos históricos para criação de uma fundação internacional de incentivo à cultura e à educação. A Fundação, que leva seu nome, está sediada na cidade de Lisboa, Portugal, onde é possível conhecer a valiosa coleção.

24 - Depoimento de Benjamin Distchekenian à autora em 05/7/2000.

25 - Ver Miller \& Miller, 1993.

26 - De acordo com Chahiniam, após a independência da Armênia em 1991, os partidos passaram por reformulações estabelecendo novas diretrizes e rumos. Depoimento à autora em 28/9/2000. 
27 - Região ocupada pelo Azerbaijão que historicamente pertencia aos reinos armênios. É constituída por maioria étnica armênia e por maioria cristã ortodoxa, além de contar com preciosos complexos arquitetônicos dos séculos XIII e XVII, e mosteiros, fortes e templos da Antigüidade e da Idade Média. Conferir Gharabagh é Armênia - Armênia é Gharabagh. São Paulo. Associação Cultural Tekeyan. Fev. de 1988.

28 - Depoimento de Hrair Chahinian à autora em 28/9/2000.

\section{Fontes: depoimentos orais}

Varvarisa Nercessian, filha de armênios, nasceu em Araçatuba, em 1930.

Sofia Gasparian, nasceu em Alexandropol (Armênia russa), em 1911.

Manuk Mardirossian, nasceu em Haini/Diarbekir, Turquia, em 1909.

Haiganuch Sarian, filha de armênios, nasceu em São José do Rio Preto, em 1938.

Archaluz Kurkdjian, filha de armênios, nasceu em São Paulo, em 1935.

Krikor Chofakian, nasceu em Sis, Armênia turca, em 1908.

Victoria Chofakian, nasceu em Sis, Armênia turca, em 1912.

Karnig Bazarian, nasceu em Marach, Armênia turca, em 1908.

Antonio Rizkallah Neto, neto de armênios, nasceu em São Paulo, em 1932.

Benjamin Distchekenian, filho de armênios, nasceu em São Paulo, em 1930.

Lucy Esther Jafferian, filha de armênios, nasceu em São Paulo, em 1936.

Yeranouhi Mavian, nasceu em Beirute, no Líbano, em 1925.

Datev Karibian, nasceu em Alepo, Síria, 1937.

Panios Kelian, filho de armênio, nasceu em Piraju, São Paulo, em 1936.

Sossi Amiralian, nasceu em Beirute, Líbano, em 1933.

Victoria Donelian, nasceu em Smirna, Turquia, em 1912.

Angel Seraidarian, nasceu em Cesaréia, atual Turquia, em 1908.

Stepan Hrair Chahinian, nasceu em Alepo, Síria, em 1947.

\section{Bibliografia}

ALEM, Jean Pierre. A Armênia. Trad. Arakcy Kafejian Martins Rodrigues. São Paulo: Difusão Européia do Livro/DIFEL, 1961. (Coleção Saber Atual)

ARCA. Ver Migração: de como árabes e armênios se instalaram em Campo Grande. In : Arca. Arquivo Histórico de Campo Grande. n. 3. dez. 1992.

ASBAREZ: Armenian Daily Newspaper. Los Angeles. Saturday, v. 92, n. 11,216. April 22, 2000.

PASCHOAL, Erlon (Trad.). Um genocídio em julgamento: O processo Talaat Paxá na República de Weimar. Trad. Erlon J. Paschoal. Rio de Janeiro: Paz e Terra, 1994.

BAZARIAN, Jacob. A trajetória de um patriota armênio: A vida e as atividades do comendador Karnig Bazarian. São Paulo: Edição do Autor, 1988.

COMUNIDADE ARMÊNIA DE OSASCO. Armênia: um país soberano que ressurge das cinzas. Osasco. Junho de 1992.

. Armênia: o povo que renasceu das cinzas. Revista comemorativa do 50 o aniversário da Igreja Apostólica Armênia São João Batista de Osasco [s/d]

FREITAS, Sônia M. de. História Oral: possibidades e procedimentos. São Paulo: Imprensa Oficial/Editora Humanitas/FFLCH-USP, 2002.

ASSOCIAÇÃO CULTURAL TEKEYAN. Gharabagh é Armênia-Armênia é Gharabagh. São Paulo: Associação Cultural Tekeyan. Fev/1988.

GRUN, Roberto. Negócios \& Famílias: armênios em São Paulo. São Paulo: Editora Sumaré, 1992. (Série imigração; v. 3). 
LE GOFF, Jacques. Memória. In: Enciclopédia Einaudi. Lisboa: Imprensa Nacional, Casa da Moeda, 1984, v. 1 - Memória e história.

MILLER, Donald E.; MILLER, Lorna Touryan. Survivors: an oral history of armenian genocide. Los Angeles. University of California, 1993.

ARQUIVO HISTÓRICO DE CAMPO GRANDE-MS. Migração: de como árabes e armênios se instalaram em Campo Grande. In: Arca. Arquivo Histórico de Campo Grande. n. 3. dez. 1992.

SOCIEDADE RECREATIVA MARACHÁ. Sociedade Beneficente e Cultura Marachá da coletividade armênia no Brasil, São Paulo, O Marachá, ano 2, n. 10, nov. 1982 e ano 13, n. 13, nov. 1983.

REVISTA ARMÊNIA. São Paulo, ano 3, n. 16, maio-jun. 1969.

SAPSEZIAN, Aharon. História da Armênia: drama e esperança de uma nação. Rio de Janeiro, Paz e Terra, 1988. . Literatura Armênia: uma introdução. Rio de Janeiro: Paz e Terra, 1994.

SHAHINIAN, Haig. Conceitos básicos da Organização Democrata Liberal Armênia. São Paulo. Associação Cultura Tekeyan, 1984.

SAROYAN, William. Inspire e expire. New Yor: Random House. 1936, pp. 437-38. Disponível em https://en.wikipedia.org/wiki/The_Armenian_and_the_Armenian Acessado em 20/05/2015.

SOCIEDADE RECREATIVA MARACHÁ: 26 anos de serviço da cultura e do progresso dos marachtsi da coletidade armênia do Brasil, São Paulo, O Marachá, 1947 - 1973. São Paulo, [197 - ?]. Edição comemorativa

SOUZA, Julio Seabra Inglez de. Uvas para o Brasil. São Paulo: Melhoramentos, 1969.

TRUZZI, Oswaldo M. Serra. Patrícios: Sírios e Libaneses em São Paulo. São Paulo: Hucitec, 1997.

\title{
RESUMO:
}

Este estudo tem por objetivo buscar o contexto histórico que determinou a vinda de armênios para o Brasil, sobretudo para o estado de São Paulo, bem como apresentar a história dessa imigração e a conseqüente constituição deste grupo étnico, tendo como base as narrativas e relatos dos próprios imigrantes e descendentes. Partindo do registro de suas memórias, na perspectiva de reconstruir parte da história social do processo imigratório para São Paulo, este artigo procura evidenciar a história dos armênios, particularmente os traços culturais e de que maneira este grupo étnico (re) construiu e vivenciou a sua identidade no país adotivo.

Palavras-chave: genocídio armênio, imigração armênia no Brasil, memórias

\begin{abstract}
:
The present study seeks to find the historic context that determined the influx of Armenians to Brazil, especially to the state of São Paulo, as well as to present the history of this immigration and the consequent constitution of this ethnic group, based on the narratives and testimonies from the immigrants themselves and their descendants. Based on the record of their memories, from the perspective of rebuilding part of the social history of the immigration process to São Paulo, this article intends to substantiate the history of the Armenians, particularly the cultural traces and how this ethnic group (re)built and experienced their identity in their adoptive country.
\end{abstract}

Keywords: armenian genocide, armenian immigration to Brazil, memories 